\title{
PENJUALAN , PENDAPATAN DAN PAJAK PERTAMBAHAN NILAIPERUSAHAAN ANGKUTAN UDARA NIAGA BERJADWAL \\ OLEH: DrS.SUDARNO,MM.
}

\begin{abstract}
Revenue comprises turnover from transportation of passenger and cargo and this provision of other services, e.g engineering and maintenance,leasing and package holidays

The treatment of passenger and cargo in external financial statements would generally appear to be consistent in industry, as a result this guideline cover both aspects of revenue without differentiating unless reference is made.

The basic principal that revenue should be recognised when transportation or carriage provided is well established.This concept is the same whether revenue passenger and cargo.This treatment reflect the application of the accruals concept(accruals basis).The airlines in effect act as collectors on value added tax from sold of passenger ticket or air way bill and other service amounting to $10 \%$ (ten percent) from face value.

Treatment of accounting policy as follows;

1.Income arisingfrom sales made where the sale coupon has been processed, but the flight is yet to take place and recorded in the accounting period as unearned revenue, included in current liabilities

2.If flight coupon has been flight to destination but have been not recorded in the account of ticket sold called unrecorded included in current asset,for value added tax purposes unrecorded can be changed to account receivables.

3.Scheduled and charterrevenue from passengers and recorded in the accounting periode as income included in statement of income.

4.All forms of cargo revenue derived from air freight and recorded in the accounting period as income included in statement of income.
\end{abstract}

\section{PENDAHULUAN.}

Pendapatan perusahaan angkutan udara niaga terdiri dari pergerakan perjalanan penumpang pesawat udara dan muatan serta penyediaan jasa lainnya seperti perawatan pesawat udara,sewa pesawat udara, paket liburan (pariwisata).
Perlakuan pendapatan dari penumpang dan muatan dalam bentuk laporan keuangan dalam industri angkutan udara pada umumnya dilaksanakan sesuai dengan standar akuntansi keuangan yang berlaku umum dan dilaksanakan dengan penuh konsisten. 
Prinsip dasar pengakuan pendapatan penumpang pesawat udara dan muatan diakui manakala dapat dibuktikan bahwa penumpang pesawat udara maupun muatan telah sampai tujuan sebagaimana yang tercantum dalam tiket penumpang dan surat muatan udara.Perlakuan tiket penumpang yang belum dilaksanakan terbang namun disebabkan oleh waktu yang sudah daluwarsa sebagai yang tercantum dalam tiket penumpang oleh perusahaan penerbangan pada umumnya diakui sebagaipendapatan penumpang melalui jurnal umum. Pajak Pertambahan Nilai dan pajak lainnya serta jasa pelayanan penumpang yang dipungut berdasarkan otorisasi negara maupun otoritas bandara bukan pendapatan perusahaan angkutan udara niaga berjadwal namun merupakan hutang kepada otoritas negara dan otoritas bandar udara.

\section{LANDASAN TEORI}

\section{A.SASARAN}

Panduan yang berhubungan pendapatan perusahaan angkutan udara niaga berjadwal mengacu kepada prinsip akrual dimana pendapatan diakui manakala flight coupon telah digunakan untuk terbang dengan tuntas.artinya sampai tujuan sebagaimana yang rute yang tercantum dalam flight coupon.
Biaya yang terkait dengan pendapatan penumpang pesawat udara niaga seperti diskon dan komisi penjualan dalam laporan keuangan harus dilaporkan dalam waktu (periode) yang sama sesuai dengan matching concept.

Dalam struktur standar akuntansi, dari International Accounting Standards

Commitee dinyatakan bahwa pendapatan diakui sebagai pendapatan penghasilan dalam periode akuntansi manakala janji dari perusahaan angkutan udara niaga berjadwal sebagaimana rute yang tercantum dalam tiket (flight coupon) terpenuhi.

\section{B. KUPON YANG TIDAK TERPENUHI JANJI}

Tiket penumpang pesawat udara untuk dapat digunakan waktu yang berbeda tergantung kepada kondisi dari penjualan dan tarif tiket penumpang pesawat udara yang dibeli,sebagai contoh umur tiket ada yang satu tahun atau bahkan lebih, manakala tiket tersebut tidak digunakan dalam waktu umur yang tercantum dalam tiket (ticket validity) maka uang yang dibayar kepada perusahaan angkutan udara niaga berjadwal tidak dapat diminta kembali 


\section{C.KOMISI DAN DISKON}

Porsi yang lebih besar penjualan tiket perusahaan angkutan udara niaga berjadwal pada umumnya dilaksanakan oleh agen penjualan tiket, dan perusahaan angkutan udara niaga berjadwal memberikan komisi sebagai jasa telah menjual tiket perusahaan tersebut,dan kadang kadang memberikan harga diskon atau potongan lainnya dengan harga yang bersaing .

Perlakuan komisi dan potongan dalam dunia perusahaan angkutan udara niaga berjadwal begitu komplek ,sesungguhnya pemberian komisi dan potongan tambahan semakin tahun semakin bertumbuh diakibatkan oleh persaingan yang semakin ketat dalam dunia angkutan udara niaga berjadwal.

Sebagian besar perusahaan angkutan udara niaga berjadwal mengakui komisi tambahan dan potongansaat tiket penumpang sudah diterbangkan, contoh

British Airways setiap bulan berikutnya menyampaikan data tiket penumpang pesawat udara yang sudah diterbangkan berikut jumlah komisi tambahan dan potongan harga kepada agen penjualan tiket. meskipun beberapa perusahaan angkutan udara niaga berjadwal memperlakukan sebagai biaya pada waktu penjualan tiket, contohnya yang berlaku perusahaan angkutan udara niaga di dalam negeri .

Pada umumnya perusahaan angkutan udara niaga berjadwal tidak konsisten dalam perlakuan akuntansi dari pada pemberian komisi,komisi tambahan, dalam laporan labadan rugi perusahaan dalam satu periode akuntansi

\section{PENDAPATAN LAINNYA.}

Disamping pendapatan dari penumpang dan angkutan barang perusahaan angkutan udara niaga berjadwal juga mendapatkan pendapatan dari ; penyewaan pesawat udara sebagai lessor, perawatan pesawat udara, pelayanan catering dan paket liburan (pariwisata).

Beberapa perusahaan angkutan udara niaga berjadwal juga mendapatkan pendapatan bukan dari usaha utamanya contoh kelebihan bagasi yang dibebankan kepada penumpang pesawat udara.

\section{E. PEMBAYARAN}

Pada dewasa ini cara pembayaran atas penjualan tiket penumpang pesawat udara banyak dilaksanakan dengan menggunakan credit card, hal tersebut pada hakekatnya akan memberatkan perusahaan angkutan udara niaga berjadwal karena harus dipungut biaya kurang lebih 2,5\%(dua setengah persen). 
Oleh karena itu ada beberapa perusahaan angkutan udara niaga berjadwal lebih senang pembayaran atas pembelian tiket penumpang dengan uang tunai atau transfer antar bank, dengan memberikan insentif berupa potongan tunai.

\section{F. PAJAK PERTAMBAHAN NILAI}

Mengingat wajib pajak perusahaan angkutan udara niaga berjadwal adalah perusahaan menengah keatas ,maka bagi nya diwajibkan menjadi Perusahaan Kena Pajak, setelah perusahaan menjadi Pengusaha Kena Pajak maka dapat melakukan penagihan/pemungutan pajak pertambahan nilai kepada para pembeli tiket penumpang maupun surat muatan udara dan jasa lainnya .

Untuk melaksanakan pungutan maka pengusaha kena pajak harus menggunakan faktur pajak.

Adapun jenis- jenis faktur pajak dimaksud adalah sebagai berikut;

1.Faktur pajak Standar,adalah faktur pajak yang dibuat sesuai dengan ketentuan sebagaimana ditetapkan dalam Kep.Dirjen Pajak no.Kep -53/PJ./1994 tertanggal 29 Desember 1994 ,yang wajib dilaksanakan oleh PKP terhitung mulai tanggal 1 Januari 1995, diperbaharui dengan UndangUndang Pajak Pertambahan Nilai No 42 tahun 2009.Faktur Pajak Standar harus dibuat dalam rangkap dua,lembar pertama untuk pembeli dan lembar kedua untuk PKP yang menerbitkan faktur pajak standar sebagai bukti pajak keluaran.

2. Faktur Pajak Gabungan,adalah faktur pajak yang dapat digunakan untuk beberapakali penyerahan Barang kena Pajak atau Jasak Kena Pajak kepada pembeli atau penerima jasa yang sama yang dilakukan dalam satu masa pajak dan harus dibuat selambat-lambatnya akhir bulan.

3.Faktur pajak sederhana, adalah dokumen yang disamakan fungsinya dengan faktur pajak yang diterbitkan oleh Pengusaha Kena Pajak sesuai dengan Peraturan Direktur Jenderal Pajak Per -27/PJ/2011 tertanggal 19 September 2011, khusus untuk perusahaan angkutan udara niaga berjadwal dengan mengacu kepada pasal 1 huruf e tentang dokumen tertentu yang kedudukannya dipersamakan dengan faktur pajak berupa; Tiket,tagihan Surat Muatan Udara(Airway Bill), atau Delivery Bill yang dibuat /dikeluarkan untuk penyerahan jasa angkutan udara dalam negeri.

Pajak Pertambahan Nilai dihitung berdasarkan tarif pajak pertambahan nilai dikalikan dengan dasar pengenaan pajaknya, tarif pajak pertambahan nilai 
adalah sebesar $10 \%$. Adapun dasar pengenaan pajak yang digunakan dalam bentuk jasa kena pajak dasar pengenaannya adalah nilai penggantinya.

Dalam bisnis perusahaan angkutanudara niaga berjadwal ,dapat menggunakan ketiga bentuk faktur pajak sesuai dengan kebutuhannya.

Faktur pajak standar, dapat digunakan untuk menagih Pajak Pertambahan Nilai atas tagihan Paket Liburan ( Pariwisata) dan lainnya.

Faktur pajak gabungan dapat dipakai untuk tagihan Pajak Pertambahan Nilai transaksi charter pesawat yang dilaksanakan beberapa kali dalam satu bulan.

Sedangkan Faktur Pajak Sederhana, pungutan Pajak Pertambahan Nilai dilaksanakan dengan menggunakan tiket penumpang dan Surat Muatan Udara.

Tempat kedudukan Pengusaha Kena Pajak,apabila Pengusaha Kena Pajak mempunyai satu atau lebih tempat kegiatan usahanya diluar tempat tinggal atau kedudukannya,setiap tempat tersebut merupakan tempat terutangnya pajak Pengusaha Kena Pajak dimaksud wajib melaporkan usahanya untuk dikokohkan sebagai Pengusaha Kena Pajak.

Apabila Pengusaha Kena Pajak terutang pajak pada lebih dari 1(satu) tempat kegiatan usaha, Pengusaha Kena Pajak tersebut dalam pemenuhan kewajiban perpajakannya dapat menyampaikan pemberitahuan secara tertulis kepada Direktut Jenderal pajak untuk memilih 1(satu) tempat atau lebih sebagai terutangnya pajak.

\section{G.TARIF TIKET PENUMPANG}

Bahwa tarif tiket penumpang pesawat udara yang dilaksanakan oleh perusahaan angkutan udara niaga berjadwal dilaksanakan berdasarkan Peraturan Menteri Perhubungan Republik Indonesia, dengan memberlakukan tarif batas atasdan tarif batas bawah ,hal tersebut juga sangat tergantung dari standar pelayanan yang diberikan kepada penumpang pesawat udara , yaitu dengan pelayanan full service, medium service dan minimum service(no frills service), serta jenis pesawat pengangkut bermesin jenis jet dan pesawat pengangkut bermesin jenis propeller sedangakan harga jual tiket terssebut sudah termasukmargin maksimal sebesar10\% (Sepuluh persen).

\section{H. GUGUS TUGAS}

Gugus tugas di perusahaan angkutan udara niaga berjadwal pada umumnya yang terkait dengan kebijakan penjualan /pendapatan adalah Direktorat Marketing, Direktorat Keuangan, Kepala Perwakilan. 
Direktorat Marketing sebagai pemangku kebijakan pemasaran, adapun ,kebijakankebijakan dimaksud adalah diantaranya, kebijakan keagenan,program IATA INA, program pelayanan, kebijakan prosedur pertiketan dan lain-lain.

Direktorat Keuangan, sebagai pemangku pengelolaan keuangan dan pengawasan, memberi masukan mengenai bidang perpajakan yang diumumkan oleh regulator perpajakan, serta akuntansi pengawasan dalam pelaksanaan dilapangan.

Kepala Perwakilan sebagai pemangku pelaksanaan akan penjualan baik penjualan yang dilaksanakan sendiri maupun penjualan yang dilaksanakan oleh agen penjualan tiket.

\section{PERLAKUAN AKUNTANSI}

Perlakuan akuntansi untuk sistem pendapatan adalah sistem akrual yaitu pendapatan diakuipada saat terjadinya transaksi tersebut bukan berdasarkan uang yang diterima, sedangkan pendapatan yang masih harus diterima dapat disebut sebagai aktiva yang masih harus diterima, dibukukan dalam aktiva lancar. Sedangkan hasil penjualan ticket, surat muatan udara dan tiket bagasi lebih yang diterima dimuka adalah merupakan kewajiban dibukukan dalam hutang lancar.
Dalam dunia angkutan udara pada umumny mengacu kepada petunjuk oleh IATA, sebelum mengacu kepada petunjuk perlakuan akuntansi oleh IATA, perlu mengetahui istilah - istilah yang penting diantaranya sebagai berikut;

Passenger Revenue, adalah pendapatan yang diperoleh dari pemegang tiket penumpang yang telah dilaksanakan terbang ketempat tujuan sebagaimana tercantum tiket penumpang pesawat udara.

Cargo Revenue,adalah pendapatan yang diperoleh dari pengiriman muatan udara yang pengiriman barangnya sudah sampai tujuan sebagaimana yang tercantum dalam surat muatan udara .

Unearned revenue adalah penjualan tiket penumpang maupun surat muatan udara yang hasil penjualannya telah dipertanggungjawabkan dan dibukukan oleh perusahaan angkutan udara yang bersangkutan.

Unrecorded revenue, adalah penumpang /surat muatan udara yang telah diterbangkan ke tempat tujuan,namum belum dipertanggung jawabkan dalam laporan penjualan perusahaan angkutan udara niaga berjadwal yang bersangkutan.

Adapun perlakuan akuntansi dalam perusahaan angkutan udara niaga Berjadwal, adalah sebagai berikut; 
1.Passenger revenue diperlakukan dalam akuntansi sebagai kelompoklaporan laba dan rugi periode yang bersangkutan .

2.Cargo revenue, demikian pula sebagaimana passenger revenue diperlakukan dalam akuntansi dalam laporan laba dan rugi (income statement) periode yang bersangkutan.

Unearned revenue .mengingat hasil penjualan tiket penumpang maupun Surat muatan udara yang sudah dipertanggung jawabkan dan dilaporkan dalam laporan penjualan tiket maupun surat muatan udara perusahaan angkutan udara yang bersangkutan, namun penumpang maupun surat muatan udara belum dilaksanakan pengangkutannya ketempat tujuan, maka diperlakukan dalam akuntansi sebagai kewajiban lancar (current liabilities).

Unrecorded revenue, adalah tiket penumpang maupun surat muatan udara

yang sudah diterbangkan oleh perusahaan angkutan udara niaga berjadwal namun belum dipertanggung jawabkan dalam laporan penjualan perusahaan angkutan udara niaga berjadwal yang bersangkutan dan diberlakukan dalam akuntansi sebagai aktiva lancar (current assets) Perlakuan akuntansi untuk pajak pertambahan nilai dibukukan sebagai pajak keluaran merupakan kewajiban Pajak Pertambahan Nilai ( current liabilities).

Sedangkan untuk Pajak masukan perlakuan akuntansi dibukukan sebagai uang muka pajak (current assets).

\section{ANALISIS}

Mengingat bahwa perlakuan akuntansi penjualan perusahaan angkutan udara

niaga berjadwal sangat berbeda dengan perlakuan akuntansi penjualan dari perusahaan niaga/dagang lainnya , maka perlu penjelasandan rincian yang jelas beberapa kriteria yang menyebabkan perbedaaan , apalagi bila dikaitkan dengan undang-undang pertambahan nilai sesuai dengan Undang - Undang Pajak Pertambahan Nilai No 42 tahun 2009. Penjualan barang dagangan dalam perdagangan umum dibukukan dalam buku besar sebagai penjualan barang dagangan termasuk dalam kelompok perkiraan laba dan rug sebagai pendapatan .Sedangkan dalam penjualan tiket penumpang pesawat udara dan surat muatan udara dan tiket bagasi lebih dibukukan di buku besar termasukdalam kelompok liabilitas bukan sebagai pendapatan, namun dalam pungutan Pajak Pertambahan Nilai tetap mengacu kepada penjualan tiket penumpang,surat muatan udara dan tiket bagasi lebih. 
Sedangkan pendapatan yang dibukukan dalam kelompok perkiraan laba dan rugi berdasarkan daftar penumpang pesawat udara dengan lampiran tiket yang berupa flight coupon selanjutnya diringkas dalam laporan pendapatan dan dibukukan sebagai pendapatan melalui jurnal umum dengan mendebet perkiraan penjualan dan mengkredit perkiraan pendapatan.

Kebijakan marketing dan keuangan perusahaan angkutan udara niaga berjadwal tentang penjualan tiketdan Surat muatan udara serta tiket bagasi lebih , perlakuan akuntansi sangat mempengaruhi jumlah Pajak Pertambahan

Nilai yang harus disetor.

Dalam menghitung besaran pajak pertambahan nilai perusahaan angkutan udara niaga berjadwal, pihak fiskus menekankan tarif yang tercantum dalam

tiket/surat muatan udara serta tiket bagasi lebih (face value), sedangkan kebijakan IATA/perusahaan angkutanudara untuk rute-rute tertentu menggunakan tarif penuh sebelum potongan (gross fare) atau published fare dengan mencantumkan kode kebijakan perusahaan angkutan udara niaga berjadwal .
Hal tersebut akan menimbulkan perbedaan persepsi dasar pengenaan pajak pertambahan nilai antara fiskus dan wajib pajak. Adapun perbedaan persepsi adalah dengan istilah dalam neraca di kelompok aktiva lancar yaitu unrecorded yang menurut fiskus sebetulnya tiket penumpang maupun surat muatan udara sudah terjual walaupun oleh agen penjualan tiket maupun surat muatan udara belum dilaporkan dan disetorkan ke perusahaan angkutan udara niaga dalam periode tiket / smu tersebut dalam periode laporan .

\section{KESIMPULAN DAN SARAN}

Untuk meminimalkan selisih perhitungan pajak pertambahan nilai yang harus disetor

1.Pada umumnyapertanggung jawaban penjualan tiket penumpang pesawat udara maupun surat muatan udara yang dilaksanakan oleh agen penjualan dalam sebulan empat kali pertanggung jawaban .

1,1. minggu pertama tanggal 1-7 dipertanggung jawabkan pada tanggal 8

1,2. minggu kedua tanggal 8-15 dipertanggung jawabkan tanggal 16

1.3. minggu ketiga tanggal 16-23 dipertanggung jawabkan tanggal 24

1.4. minggu keempat tanggal 24-31 dipertanggung jawabkan tanggal 1 bulan 
berikutnya.

Pada penjualan minggu keempat inilah yang menimbulkan unrecorded revenue, yaitu tiket penumpang maupun surat udara yang sudah diterbangkan sampai tujuan namun belum dipertanggung jawabkan dalam buku penjualan perusahaan angkutan udara niaga berjadwal yang Bersangkutan dan baru dipertanggung jawabkan berikut pembayaran dilaksanakan pada tanggal satu bulan berikutnya.

Mengingat pengolahan data pada saat ini sudah komputerisasi tegasnya sudah on line maka perusahaan angkutan udara niaga berjadwal dalam periode bulan bersangkutan dapat langsung melaksanakan jurnal dengan mendebet perkiraan piutang dagang (account receivable) dan mengkredit perkiraan penjualan( account sales).

Dengan demikian tidak ada lagi istilah unrecorded atau dengan kata lain tidak ada istilah tiket penumpang maupun surat muatan udara yang sudah diterbangkan belum dipertanggung jawabkan dalam buku penjualan.

Sedangkan untuk unearned revenue ( liabilitas ) tidak menjadi masalah karena

Pihak fiskus menghitung besarnya pajak pertambahan nilai dari penjualan tiket penumpang dan surat muatan udara walaupun belum diterbangkan.

2.Untuk produk-produk yang menggunakan perjanjian dengan agen2, seperti

Paket liburan ( pariwisata) seyogyanya menggunakan faktur tagihan dengan diikuti faktur pajak standar dan bila ada potongan harga agar dicantumkan dalam faktur sehingga jumlah tagihan menjadi net sebagai dasar pungutan pajak pertambahan nilai, Dalam tiket ,pada tour code(PW), sedangkan dalam fare basis dicantumkan code produk liburan/ pariwisata atau no surat perjanjian serta dalam kolom conjuction dicantumkan nomor voucher hotel sedangkan dalam kolom tarif Nil karena fungsi tiket penumpang tersebut sebagai dasar untuk dapat digunakan untuk terbang sedangkan perhitungan pajak pertambahan nilai diperhitungkan dalam faktur pajak gabungan.

3.Untuk pendapatan-pendapatan tertentu seperti disebutkan dalam nomor 2 , seyogyanya perusahaan angkutan udaraniaga berjadwal berkonsultasi dengan fihak fiskus, karena pada dasarnya walaupun harga tiket yang digunakan berdasarkan Permen Menteri Perhubungan , namun pada kenyataannya perusahaan 
angkutan udara menerima lebih kecil karena ada potongan harga.

4.Perusahaan angkutan udara niaga berjadwal harus melakukan rekonsiliasi

dengan seksamaantara penjualan dan pendapatan serta jumlah pajak pertambahan nilai dengan benar, sehingga perbedaan jumlah pajak pertambahan nilai yang disetor jumlahnya tidak besar bahkan kalau perlu tidak ada selisih.

5,Untuk penjualan bagasi lebih tidak ada masalah karena pajak pertambahan nilai dipungut saat penumpang melaksanakan penerbangan, sehingga periode penjualan dan pendapatan pada masa yang sama.

6.Untuk penjualan/pendapatan yang lain seperti pelayanan catering dan lain - lain tidak ada masalah karena pungutan dengan faktur pajak gabungan mengacu pada perjanjian sebagai dasar tagihan, sepanjang dalam faktur tagihan apabila ada potongan harga dicantumkan sehingga jumlah faktur yang ditagih adalah net sebagai dasar membuat faktur pajak gabungan.

7.Untuk memudahkan mengatur arus kas dan memudahkan pengawasan penyetoran Pajak Pertambahan Nilai, Pengusaha Kena Pajak, khususnya perusahaan angkutan udara niaga berjadwal, dimana tiket penumpang yang dijual namun tiket tersebut digunakan terbang dari bandar udara diluar tempat penjualan tiket penumpang tersebut sesuai dengan rute yang tertera dalam tiket penumpang maka sebaiknya pajak terutang dan disetor kepada negara dengan pemusatan ,untuk hal tersebut perusahaan angkutan niaga berjadwal harus menyampaikan pemberitahuan kepada Direktur Jenderal Pajak. mengenai pemusatan tersebut dengan mengacu kepada peraturan dan

perundang - undangan yang berlaku.

Dengan demikian manakala masingmasing pihak menggunakan aturan yang benar maka perbedaan akan terkikis dengan sendirinya bak batu yang tertetes air sepanjang masa.

\section{DAFTAR PUSTAKA}

1.Warren,Fees, Reeve,Accounting 18 th Edition

2.Peraturan Menteri Perhubungan no.91 tahun 2014,tentang

Mekanisme Formulasi dan Penetapan Tarif Batas Atas Pelayanan

Kelas Ekonomi Angkutan Udara Niaga. 3.Undang-Undang Pajak Pertambahan Nilai No.42 Tahun 2009

4.Peraturan Direktur Jenderal Pajak No.27/PJ/2011,19 Desember 2011

Tentang Dokumen Tertentu Yang Kedudukannya Dipersamakan Dengan

Faktur Pajak

5.Susunan dalam satu naskah9(sembilan) Undang-Undang Perpajakan,

Penerbit Ortax, Jakarta.

6.IATA,Airlines Accounting Guidelines, Recognition of Revenue 